\title{
Nephrologic abnormalities in neonatal asphyxia at Cipto Mangunkusumo Hospital, Jakarta
}

\author{
Idham Amir, MD; Vera M Manoe, MD; Taralan Tambunan, MD
}

\begin{abstract}
Introduction Neonatal asphyxia is still the leading cause of high morbidity and mortality in developed countries, as well as in developing countries including Indonesia. As a response to asphyxia, renal hypoxia occurs which is initially temporary, but if persisting, can cause permanent damage to the cortex and medulla.

Objective The purpose of this study was to determine the nephrologic abnormalities in neonatal asphyxia at Cipto Mangunkusumo Hospital.

Methods This was a cross sectional descriptive study conducted in the Division of Neonatology, Cipto Mangunkusumo Hospital from August until November 2002. Neonates with congenital malformation were excluded.

Results The study showed that the incidence of nephrologic abnormalities in neonatal asphyxia based on Apgar scores at 1, 5, and 10 minutes were $65 / 100,26 / 33$, and 5/6, respectively. The risk of nephrologic abnormalities was not statistically different in severe asphyxia compared to moderate asphyxia. Severe asphyxia at 1 minute Apgar scores was correlated with the occurrence of oliguria.

Conclusion In asphyxiated newborn, it is very important to investigate the possibility of nephrologic abnormalities [Paediatr Indones 2004;44:66-72].
\end{abstract}

Keywords: nephrologic abnormalities, neonatal asphyxia, oliguria, Apgar scores

I $n$ developed countries, the incidence of neonatal asphyxia varies from $0.3-0.9 \%$ of all live births. ${ }^{1}$ In developing countries, the incidence is higher than that in developed countries due to inadequate neonatal care. ${ }^{1,2}$ In Indonesia, the incidence of neonatal asphyxia is approximately $3-5 \%$ of all live births. ${ }^{2}$ During asphyxia, blood flow is redistributed to vital organs (brain, heart, and adrenal glands) so that other organs, such as kidneys, will receive less blood flow. ${ }^{1-4}$ Renal hypoxia that occurs during the first 24 hours of life will cause renal ischemia which is initially reversible but if hypoxia persists, it can cause permanent renal damage. ${ }^{5}$ Dauber discovered that 4 out of 7 asphyxiated neonates suffered from renal failure with oliguria as the main symptom accompanied with increased blood urea nitrogen and creatinine. ${ }^{5}$ Karlowicz reported that acute renal failure occurred in $61 \%$ infants with severe asphyxia, $60 \%$ of which was non-oliguric, $25 \%$ was oliguric, and the remaining $15 \%$ was anuric type. ${ }^{6}$

The purposes of this study were to determine the profile and incidence of nephrologic abnormalities in neonatal asphyxia at Cipto Mangunkusumo Hospital, the effect of the degree of asphyxia on nephrologic abnormalities, and the effect of asphyxia based on Apgar scores at 1, 5, and 10 minutes on nephrologic abnormalities.

\section{Methods}

A cross-sectional descriptive study was conducted prospectively in the Division of Neonatology, Cipto

From the Department of Child Health, Medical School, University of Indonesia, Cipto Mangunkusumo Hospital, Jakarta.

Reprint requests to: Idham Amir, MD, Department of Child Health, Medical School, University of Indonesia, Cipto Mangunkusumo Hospital, Jakarta, Indonesia. Tel. 62-21-3907740, Fax. 62-21-3907743. 
Idham Amir et al: Nephrologic abnormalities in neonatal asphyxia

Mangunkusumo Hospital from August to November 2002. All neonates with birth asphyxia (Apgar scores $\leq 6)$ were included in this study. Neonates with congenital malformation, incomplete data, and parents' refusal to sign the informed consent were excluded from the study. Sample size of 100 , determined using single sample formula, was considered sufficient to demonstrate significant findings in estimating the proportion of population.

Apgar scores at 1, 5, and 10 minutes to determine the degree of asphyxia were assessed by trained residents. The degree of asphyxia was categorized as normal (no asphyxia), moderate, and severe based on the Apgar scores at 1, 5, and 10 minutes. The neonate was normal if the score was $7-10$, moderately asphyxiated if the score was 4-6, and severely asphyxiated if the score was $0-3$. Neonates with birth asphyxia who fulfilled the inclusion criteria were analyzed in three separate groups. The AS-1 (Apgar score at 1 minute) group consisted of neonates with the Apgar scores at 1 minute of $\leq 6$. The AS-5 (Apgar score at 5 minutes) group consisted of neonates with Apgar scores at 1 and 5 minutes of $\leq 6$. The AS-10 (Apgar score at 10 minutes) group consisted of neonates with Apgar scores at 1, 5, and 10 minutes of $\leq 6$. Recording of baseline data included identity, birth weight, body length, gestational age, and method of delivery. The onset of first micturition was observed. The urine was collected using a urine collector in male neonates and a modified plastic bag that could be used as underpants in females. For female neonates who were menstruating, urine samples were obtained through suprapubic aspiration. Urinalysis of the first urine specimen was performed. Urine specific gravity was determined using a refractometer. Then, urine was collected for 24 hours after the first micturition. In male neonates, urine collection was done using a plastic bag. Every 3 hours, urine volume was measured using a measuring beaker. Weighing diapers determined urine output in female neonates every 3-4 hours using a scale with a 10 -gram sensitivity.

Serum creatinine level of the neonates was measured at 36-48 hours after birth. Serum creatinine level of the mother was also measured. The measurement was done using a deproteinization method with Clinicon 4010. Renal function assessment was determined using Schwartz formula, as follows:

\section{$\mathrm{GFR}=\underline{\mathrm{k} \times \mathrm{L}}$ \\ $\mathrm{Pcr}$}

where

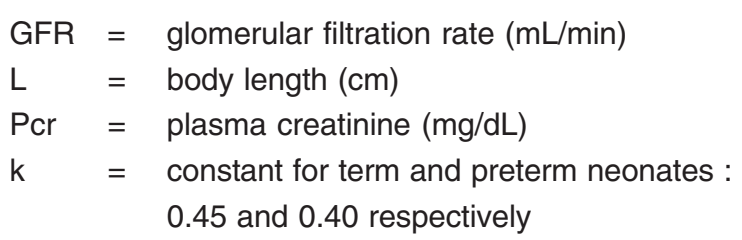

Nephrologic abnormality was defined as the presence of at least 1 abnormality of the following variables: delayed micturition, oliguria, elevated serum creatinine, decreased GFR, decreased urine specific gravity, and hematuria. The first micturition was considered normal if it occurred in 0-24 hours after birth. Oliguria was defined as urine output of $<1 \mathrm{~mL} / \mathrm{kg} /$ hour. Hematuria was defined as $>5$ erythrocytes/high power fields in urinary sediment. Normal urine specific gravity ranged between 1.015-1.030. The normal serum creatinine levels in term and preterm neonates aged 2 days were $0.84 \pm 0.4 \mathrm{mg} /$ $\mathrm{dL}$ and $1.05 \pm 0.5 \mathrm{mg} / \mathrm{dL}$, respectively, whereas the normal value in adult females was $0.72 \pm 0.19 \mathrm{mg} / \mathrm{dL}$. Serum creatinine level of the neonates was considered elevated if at the age of 2 days, it was higher than the normal value whereas at the same time the mother's serum creatinine level was normal. The normal values of glomerular filtration rate (GFR) in neonates of 32-34week gestation and $>35$-week gestation were $14 \pm 3$ and $21 \pm 4 \mathrm{~mL} / \mathrm{m} / 1.73 \mathrm{~m}^{2}$, respectively.

This study had ethical clearance from the Ethics Committees of Medical School, University of Indonesia. Written parental consent was obtained from all subjects.

Data were analyzed using an SPSS 10.0 computer program. Statistical analysis of the data was performed using the chi-square test or Fisher exact test. Significance was defined as $p<0.05$. To assess the degree of correlation between each independent variable and nephrologic abnormalities, a ratio of prevalence was determined with a confidence interval of $95 \%$. The comparison between various independent variables was analyzed using logistic regression.

\section{Results}

During the period of study (August-November 2002), 103 newborn babies were investigated. Three neonates 
Table 1. Characteristics of asphyxiated infants

\begin{tabular}{llll}
\hline Sample characteristics & AS-1 (n=100) & AS-5 (n=33) & AS-10 (n=6) \\
\hline Birth weight (g), mean (SD) & $2535.6(838.3)$ & $2300(755)$ & $2043.3(1058.1)$ \\
Body length (cm), mean (SD) & $45.2(5.1)$ & $43(5.6)$ & $42.33(5.9)$ \\
Gestational age (week), mean (SD) & $37.4(2.3)$ & $37(2.4)$ & $35.7(3.4)$ \\
Sex & & & \\
$\quad$ Male & 54 & 18 & 0 \\
$\quad$ Female & 46 & 15 & 1 \\
Delivery & & 14 & 4 \\
$\quad$ Vaginal delivery & 39 & 11 & 1 \\
$\quad$ Cesarean section & 40 & 4 & 0 \\
$\quad$ Vacuum extraction & 10 & 4 & \\
$\quad$ Forceps extraction & 11 & 29 & 5 \\
Degree of asphyxia & & 4 & 1 \\
$\quad$ Moderate & 69 & & \\
$\quad$ Severe & 31 & &
\end{tabular}

Table 2. Distribution of nephrologic abnormalities in the AS-1, AS-5, and AS-10 GROUPS

\begin{tabular}{lccllll}
\hline Asphyxia & \multicolumn{2}{l}{ Nephrologic abnormalities } & Total & p & PR & 95\%Cl \\
\cline { 2 - 3 } & Negative & Positive & & & & \\
\hline AS-1 & & & & & & \\
$\quad$ Moderate & 30 & 39 & 69 & 0.258 & 1.848 & $0.723 ; 4.725$ \\
$\quad$ Severe & 5 & 26 & 31 & & & \\
$\quad$ Total & 35 & 65 & 100 & & & \\
$\begin{array}{c}\text { AS-5 } \\
\quad \text { Moderate }\end{array}$ & 7 & 22 & 29 & 0.55 & - & - \\
$\quad$ Severe & 0 & 4 & 4 & & & \\
$\quad$ Total & 7 & 26 & 33 & & & \\
AS-10 & & & & & - \\
$\quad$ Moderate & 1 & 4 & 5 & 1 & - & - \\
$\quad$ Severe & 0 & 1 & 1 & & & \\
$\quad$ Total & 1 & 5 & 6 & & & \\
\hline
\end{tabular}

were excluded due to incomplete data, so 100 neonates were eligible for further analysis.

\section{Subjects'characteristics}

The clinical characteristics of the patients are listed in Table 1.

The mean gestational age in the AS-10 group was lower compared to those of the AS-5 group and the AS-1 group. The birth weight and body length of the AS-10 group were smaller compared to those of the AS-5 group and the AS-1 group.

\section{Nephrologic abnormalities}

Sixty-five out of 100 neonates at the AS-1 group, 26 out of 33 neonates at the AS-5 group, and 5 out of 6 neonates at the AS-10 group suffered from nephrologic abnormalities as seen in Table 2 . The risk of nephrologic abnormalities was not significantly different in severe asphyxia compared to moderate asphyxia in all three phases of observation.

\section{Bivariate analysis}

Bivariate analysis was performed to analyze the strength of correlation between each independent variable (the degree of asphyxia based on AS-1, 5, and 10) and dependent variables (first micturition, oliguria, creatinine serum, GFR, urine specific gravity, and hematuria). Delayed micturition was detected in 3 out of 31 neonates with severe asphyxia at 1 minute observation (AS-1), 3 out of 29 moderate asphyxia in the AS -5 group, and 2 out of 5 moderate asphyxia in the AS-10 group. Statistically, a strong association was detected between the occurrence of delayed micturition and the severity of asphyxia in all three phases of observation. (AS-1: $p=0.028$; AS -5: 
$p=0.034 ;$ AS-10: $p=0.009$ ). At AS-10 observation, higher prevalence ratio (PR) was detected on moderate asphyxia compared to normal neonates $(\mathrm{PR}=62 ; 95 \% \mathrm{CI} 4.3 ; 887.7)$. The same results were also obtained when we compared moderate and severe asphyxia ( $\mathrm{PR}=46.5 ; 95 \% \mathrm{CI} 3.4 ; 626.5)$.

In the AS-1 group, oliguria was detected in 10 out of 31 neonates with severe asphyxia and 4 out of 69 with moderate asphyxia; while in the AS-5 group, 3 out of 4 neonates with severe asphyxia, 8 out of 29 with moderate asphyxia, and 3 out of 67 normal neonates had oliguria. In the AS-10 group, 1 neonate with severe asphyxia, 3 out of 5 neonates with moderate asphyxia, and 10 out of 94 normal neonates had oliguria. Statistically, a strong association was detected between the occurrence of oliguria and the degree of asphyxia in all three phases of observation. (AS-1: $p=0.001$; AS-5: $p=<0.001$; AS-10: $p=0.03)$. In the AS-1 group, higher prevalence ratio (PR) of nephrologic abnormalities was detected in severe asphyxia compared to moderate asphyxia $(\mathrm{PR}=7.7$; 95\%CI 2.1;27.2). The same results were also obtained when we compared moderate and severe asphyxia in one hand to normal neonates in the other hand in the AS-5 and AS- 10 groups (AS-5: $\mathrm{PR}=10.6 ; 95 \% \mathrm{CI}$ 2.7;4.7; AS-10: $\mathrm{PR}=16.8 ; 95 \% \mathrm{CI} 2.7 ; 103.6)$.

Statistical analysis revealed no correlation between the degree of asphyxia and the occurrence of nephrologic abnormalities such as decreased urine specific gravity and hematuria in severely and moderately asphyxiated infants (Table 3 ).

\section{Multivariate analysis}

Logistic regression analysis was performed to determine the correlation between independent variable (the degree of asphyxia at AS-1, 5, and 10) with the first micturition and oliguria. The result showed that the correlation between Apgar scores at 1,5 , and 10 minutes with delayed micturition was not significant $(\mathrm{PR}=9.00 ; 95 \% \mathrm{CI} 0.6 ; 125.3)$. The prevalence ratio of oliguria between moderate and severe asphyxia based on AS-1, 5, and 10 is shown in Table 4.

Table 3. Prevalence ratio of nephrologic abnormalities between moderate and seVere asphyXia based on Apgar SCORES AT 1,5 , AND 10 MINUTES

\begin{tabular}{|c|c|c|c|c|c|c|c|c|c|c|c|c|c|c|c|c|}
\hline \multirow[t]{3}{*}{ Asphyxia } & \multicolumn{2}{|l|}{ GFR } & \multirow[t]{3}{*}{$P$} & \multirow[t]{3}{*}{ PR } & \multirow[t]{3}{*}{$95 \% \mathrm{Cl}$} & \multicolumn{2}{|c|}{ Hematuria } & \multirow[t]{3}{*}{$p$} & \multirow[t]{3}{*}{ PR } & \multirow[t]{3}{*}{$95 \% \mathrm{Cl}$} & \multirow{2}{*}{\multicolumn{2}{|c|}{$\begin{array}{l}\text { Urine specific } \\
\text { gravity }\end{array}$}} & \multirow{3}{*}{$p$} & \multirow[t]{3}{*}{ PR } & \multirow[t]{3}{*}{$95 \% \mathrm{Cl}$} & \multirow[t]{3}{*}{ Note } \\
\hline & \multirow[t]{2}{*}{$\mathrm{N}$} & \multirow[t]{2}{*}{$\downarrow$} & & & & \multirow[t]{2}{*}{$\overline{(-)}$} & \multirow[t]{2}{*}{$(+)$} & & & & & & & & & \\
\hline & & & & & & & & & & & $\mathrm{N}$ & $\downarrow$ & & & & \\
\hline \multicolumn{17}{|l|}{ AS-1 } \\
\hline Severe & 16 & 15 & 1 & 1.023 & $\begin{array}{l}0.438 \\
2.388\end{array}$ & 29 & 2 & 0.720 & 0.526 & $\begin{array}{l}0.105 \\
2.634\end{array}$ & 22 & 9 & 0.087 & 2.414 & $\begin{array}{l}0.866 \\
6.727\end{array}$ & $\begin{array}{l}\text { Severe/ } \\
\text { moderate* }\end{array}$ \\
\hline Moderate & 36 & 33 & & & & 61 & 8 & & & & 59 & 10 & & & & \\
\hline Total & 52 & 48 & & & & 90 & 10 & & & & 81 & 19 & & & & \\
\hline \multicolumn{17}{|l|}{ AS-5 } \\
\hline Severe & 2 & 2 & 1 & 1.161 & $\begin{array}{l}0.154 \\
8.736\end{array}$ & 3 & 1 & 0.426 & 2.458 & $\begin{array}{l}0.227 \\
26.578\end{array}$ & 4 & 0 & 1 & - & - & $\begin{array}{l}\text { Severe/ } \\
\text { normal }^{*}\end{array}$ \\
\hline Moderate & 14 & 15 & 0.664 & 1.244 & $\begin{array}{l}0.520 \\
2.977\end{array}$ & 28 & 1 & 0.270 & 0.263 & $\begin{array}{l}0.031 \\
2.210\end{array}$ & 20 & 9 & 0.094 & 2.565 & $\begin{array}{l}0.912 \\
7.218\end{array}$ & $\begin{array}{l}\text { Moderate/ } \\
\text { normal }^{*}\end{array}$ \\
\hline Normal & 36 & 31 & 0.674 & 1.234 & $\begin{array}{l}0.536 \\
2.843\end{array}$ & 59 & 8 & 0.490 & 0.476 & $\begin{array}{l}0.095 \\
2.379\end{array}$ & 57 & 10 & 0.177 & 2.138 & $\begin{array}{l}0.772 \\
5.922\end{array}$ & $\begin{array}{l}\text { Severe + } \\
\text { moderate/ } \\
\text { normal }^{*}\end{array}$ \\
\hline Total & 52 & 48 & & & & 90 & 10 & & & & 81 & 19 & & & & \\
\hline \multicolumn{17}{|l|}{ AS-10 } \\
\hline Severe & 1 & 0 & 1 & - & - & 1 & 0 & 1 & - & - & 1 & 0 & 1 & - & - & $\begin{array}{l}\text { Severe/ } \\
\text { normal }^{*}\end{array}$ \\
\hline Moderate & 3 & 2 & 1 & 0.696 & $\begin{array}{l}0.111 \\
4.355\end{array}$ & 4 & 1 & 0.420 & 2.361 & $\begin{array}{l}0.238 \\
23.468\end{array}$ & 5 & 0 & 0.580 & - & - & $\begin{array}{l}\text { Moderate/ } \\
\text { normal }^{*}\end{array}$ \\
\hline Normal & 48 & 46 & 0.679 & 0.522 & $\begin{array}{l}0.091 \\
2.987\end{array}$ & 85 & 9 & 0.478 & 1.889 & $\begin{array}{l}0.198 \\
\text { 17. } 998\end{array}$ & 75 & 19 & 0.592 & - & - & $\begin{array}{l}\text { Severe + } \\
\text { moderate/ } \\
\text { normal }^{*}\end{array}$ \\
\hline Total & 52 & 48 & & & & 90 & 10 & & & & 81 & 19 & & & & \\
\hline
\end{tabular}


Table $4 . \quad$ Prevalence ratio of oliguria between moderate and SEVERE ASPHYXIA BASED ON APGAR SCORES AT 1, 5, AND 10 MINUTES (AFTER ADJUSTMENT)

\begin{tabular}{llllll}
\hline Risk factor & Bivariate & \multicolumn{4}{l}{ Multivariate } \\
\cline { 2 - 5 } & PR & $\mathbf{9 5 \%} \mathbf{C l}$ & PR & $\mathbf{9 5 \%} \mathbf{C l}$ & \\
\hline AS-1 & 7.738 & $2.196 ; 27.269$ & 2.175 & $1.024 ; 4.619$ & S \\
AS-5 & 10.667 & $2.723 ; 41.785$ & 0.291 & $0.663 ; 3.933$ & NS \\
AS-10 & 16.8 & $2.723 ; 103.647$ & 0.261 & $0.281 ; 1.411$ & NS \\
\hline
\end{tabular}

Note: $\mathrm{S}$ = significantNS: not significant

Results using bivariate analysis showed that severe asphyxia statistically affected the occurrence of oliguria in all the three phases of observation with the prevalence ratio of $7.738,10.667$, and 16.8 respectively. But in multivariate analysis, the impact of asphyxia on the prevalence of oliguria was only significant in the AS-1 group with the prevalence ratio of 2.175 (95\%CI 1.02;4.619).

\section{Discussion}

Several limitations in this study, such as in evaluating Apgar scores, urine collection, and the determination of serum creatinine concentration, were identified. The method of urine collection in the female infants by means of weighing diapers, instead of using a urine catheter, was inappropriate. But due to the risk of urinary tract infection and financial reasons in using a urine catheter, urine output was determined by weighing diapers every 3-4 hours. The method of urine collection in male infants by using a plastic bag was also inappropriate because of the risk of spilling. In an effort to minimize the risk, urine was aspirated from the plastic bag every 3 hours and urine volume was measured with a measuring beaker.

The measurement of the infants' serum creatinine concen-tration on the second day accompanied with measurement of the mothers' serum creatinine concentration was also inappropriate. Ideally, the infant serum creatinine should be examined at least twice to determine if it was stable, elevated, or decreased, but this procedure was not possible in our hospital setting.

Ideally, during delivery there should be two attendants standing by, 1 person doing the resuscitation while the other determining the Apgar scores. In this study, only one pediatric resident did the resuscitation and determined the Apgar scores simultaneously, thereby making the determination of Apgar scores might be inappropriate.

\section{Subjects' characteristics}

The gestational age, birth weight, and birth length in the AS-10 group were lower than those of the AS-1 and AS-5 group. The literature stated that an Apgar score of 6-7 was normal for preterm babies. ${ }^{7}$ In term neonates, although the number of nephrons is the same as older children, their physiologic function is not fully developed yet. In preterm neonates, renal maturation process is still incomplete. The difference in the sample characteristics especially in the AS-10 group probably influenced the proportion of nephrologic abnormalities in each group.

\section{Incidence of nephrologic abnormalities in asphyxia group}

Nephrologic abnormalities were detected in 65 (65\%) out of 100 infants in the AS-1 group, 26 out of 33 infants in the AS-5 group and 5 out of 6 infants inthe AS-10 group. Similar findings was reported by Carter, who found that 9 out of 11 infants with severe asphyxia showed a disturbed renal function. ${ }^{9}$

\section{Effect of degree of asphyxia on nephrologic abnormalities}

From the data listed in Table 2, it is clear that the risk of nephrologic abnormalities in severe asphyxia was not statistically different compared to moderate asphyxia. Bivariate analysis showed that from the 6 variables evaluated, only 2 variables had significant correlations with AS-1, 5, and 10 i.e., delayed micturition and oliguria.

\section{First micturition}

Statistical analysis showed a significant association between the degree of asphyxia and the occurrence of delayed first micturition in all three phases of observations (AS-1, 5, and 10). This was probably 
due to the fact that the average bladder capacity of term infants is $30 \mathrm{~mL}$, whereas the urine output decreased from $10 \mathrm{~mL} / \mathrm{kg} /$ hour (in fetus) to 2.5 $\mathrm{mg} / \mathrm{kg} /$ hour so that several hours were needed to fill the bladder and stimulate micturition. ${ }^{8}$ Some literatures stated that in neonatal asphyxia, a temporary bladder paralysis could occur so that the first micturition could be delayed. ${ }^{1}$ Mawardi reported only one out of 44 hypoxic infants in his study that had delayed micturition up to the second day after birth, but Clark found that all of the 8 infants in his study had delayed micturition for more than 24 hours. ${ }^{10,11}$ Some undetected independent variables might play roles so that our results were different from those stated in the literatures. Theoretically, delayed micturition might be a direct consequence of neonatal asphyxia during labour. ${ }^{1,3}$

\section{Oliguria}

During hypoxia, vasoconstriction of the afferent arterioles can occur which may decrease the blood flow to the kidneys so that glomerular filtration rate decreases leading to oliguria and even anuria. Oliguria is the initial sign of acute renal failure in neonates, but if properly managed, the damage is reversible. ${ }^{5,12,13}$

In this study, 4 out of 69 infants with moderate asphyxia at 1 minute and 10 out of 31 infants with severe asphyxia at 1 minute had oliguria. The analysis to obtain prevalence ratio showed that AS-1, 5, and 10 were indeed risk factors for oliguria. But after logistic regression analysis was performed, only AS-1 was the risk factor for oliguria (Table 4). This was probably due to the fact that infants with severe asphyxia have been properly managed at the early stage during resuscitation so that an irreversible renal damage could be prevented. Therefore oliguria was no longer present in the AS-5 and AS-10 group. Some literatures stated that prolonged renal hypoxia could cause a permanent damage to the cortex and medulla. ${ }^{5}$ In this study, one infant who suffered from severe asphyxia until the $10^{\text {th }}$ minute of observation had only oliguria without subsequent elevation of creatinine level or decrease of GFR. But no conclusion can be drawn from these very limited data.
Lubis, Perlman, and Karlowicz reported that the prevalence rate ranged from 10 to $42 \%$ in asphyxiated infants who suffered from oliguria. $6,14,15$

\section{Multivariate analysis}

Multivariate analysis was done to those variables that showed significant statistic result in bivariate analysis. Those variables were severe asphyxia based on Apgar scores at 1, 5, and 10 minutes against the occurrence of delayed micturition and oliguria. There was no significant statistical difference between Apgar scores at 1, 5, and 10 minutes and delayed micturition $(\mathrm{RP}=9.00 ; 95 \% \mathrm{CI} 0.64 ; 125.35)$. This finding reflected that in bivariate analysis there was other variable that synergistically played a role in the occurrence of delayed micturition. In this study, only 3 out of 100 asphyxiated infants had delayed micturition, which presumably affected the result of logistic regression.

In bivariate analysis, the risk of oliguria was 7 times higher in severe asphyxia (based on Apgar scores at 1 minute) compared to moderate asphyxia, while in multivariate analysis the prevalence ratio decreased to 2.1 (Table 4). It means that in bivariate analysis there was a synergistic factor that played a role in the occurrence of oliguria. At the Apgar scores of 5 and 10 minutes, neonatal asphyxia was also considered to affect the occurrence of oliguria, but after adjustment was done to eliminate synergistic factors, the risk of oliguria decreased to a level of non-significant value.

We concluded that the incidence of nephrologic abnormalities in neonatal asphyxia at Cipto Mangunkusumo Hospital based on AS-1, 5, and 10 were 65 out of 100,26 out of 33 , and 5 out of 6 respectively. The risk of nephrologic abnormalities in severely and moderately asphyxiated infants is not statistically different. Severe asphyxia based on AS-1 was a risk factor for oliguria; the greater the degree of asphyxia, the higher the risk of oliguria is. Although the occurrence of oliguria in this study did not progress to renal failure, the investigation of renal function in every case of neonatal asphyxia is still needed at least to evaluate whether the treatment of asphyxia had been instituted properly. 


\section{References}

1. Aminullah A. Konsekuensi kelainan sistemik berbagai organ tubuh akibat hipoksia dan iskemia neonatus. In: Suradi R, Monintja HE, Amalia P, Kusumowardhani D, editors. Penanganan mutakhir bayi prematur: memenuhi kebutuhan bayi prematur untuk menunjang peningkatan kualitas sumber daya manusia. Naskah Lengkap Pendidikan Kedokteran Berkelanjutan Ilmu Kesehatan Anak FKUI XXXVIII. FKUI; 1997 April 7-8; Jakarta: Balai Penerbit FKUI; 1997. p. 165-84.

2. Alisjahbana A, Hidayat S, Mintardaningsih, Primardi A, Harliany E, Sofiatin Y, et al. Management of birth asphyxia at home and health center. Paediatr Indones 1999;39:88-101.

3. Glucman PD, Tan W, Mallard C, Williamms CE. Pathophysiology of perinatal asphyxia. In: Shankaran S, editor. Clinics in perinatology perinatal asphyxia. Philadelphia: Saunders; 1993. p. 305-26.

4. Indarso F. Dampak jangka panjang bayi asfiksia. Proceedings of the $11^{\text {th }}$ National Congress of Pediatrics; 1999 Jul 4-7; Jakarta, Indonesia. p. 547-57.

5. Dauber IM, Krauss AM, Symchych PS, Aula PAM. Renal failure following perinatal anoxia. J Pediatr 1976;88:851-5.

6. Karlowicz MG, Adelman RA. Nonoliguric and oliguric acute renal failure in asphyxiated term neonates. Pediatr Nephrol 1995;9:718-22.
7. Snyder EY, Cloherty JP. Perinatal asphyxia. In: Cloherty JP, Stark AR, editors. Manual of neonatal care. $4^{\text {th }}$ ed. Philadelphia: Williams \& Wilkins; 1998. p. 515-33.

8. Alatas $\mathrm{H}$. Penilaian fungsi ginjal pada neonatus. In: Marnoto W, Pusponegoro TS, Monintja HE, editors. Masalah ginjal dan saluran kemih di bidang perinatologi. Perinatologi tahun 2000. Jakarta: Balai Penerbit FKUI; 1994. p. 7-14.

9. Carter BS, Nabb FM, Merenstein B. Prospective validation of a scoring system for predicting neonatal morbidity after acute perinatal asphyxia. J Pediatr 1998; 132:619-23.

10. Mawardi H. Gangguan fungsi ginjal pada hipoksia neonatorum. MDK 1992;11:17-9.

11. Clark DA. Times of first void and first stool in 500 newborns. Pediatrics 1977; 60:457-9.

12. Kosnadi L. Nefrologi neonatal. In: Alatas H, Tambunan T, Trihono PP, Pardede SO, editors. Buku ajar nefrologi anak. $2^{\text {nd }}$ ed. Jakarta: Balai Penerbit FKUI; 2002. p. 511-49.

13. Toth-Heyn P, Drukker A, Guignard JP. The stressed neonatal kidney: from pathophysiology to clinical management of neonatal vasomotor nephropathy. Pediatr Nephrol 2000;14:227-39.

14. Lubis EN. Pengaruh asfiksia neonatorum terhadap fungsi ginjal [thesis]. Medan: Medical School, Univ of Sumatera Utara; 2000.

15. Perlman JM, Tack ED, Martin T, Shackelford, Amon E. Acute systemic organ injury in term infants after asphyxia. Am J Dis Child 1989;143:617-20. 